\title{
PERCEPTION OF SEVERITY LEVEL AND DECISION MAKING OF FAMILY CORRELATION TOWARD DEPARTING INTERVAL OF ISCHEMIC STROKE PATIENT
}

\author{
Fajri Andi Rahmawan ${ }^{1}$, Yuyun Yueniwati ${ }^{2}$, Tony Suharsono ${ }^{3}$ \\ Correspondence: fajriandiOr.fa@gmail.com \\ ${ }^{1}$ Department of Nursing, Institute of Health Sciences Banyuwangi, Banyuwangi, Indonesia \\ ${ }^{2}$ Department of Radiology, Medical Faculty, Brawijaya University, Malang, Indonesia \\ ${ }^{3}$ Department of Nursing, Medical Faculty, Brawijaya University, Malang, Indonesia
}

\section{Article History:}

Received: January 22, 2020

Accepted: March 24, 2020

Published: July 1, 2020

\section{Cite this as:}

Rahmwan FA, Yueniwati Y, Suharsono T. Perception of severity level and decision making of family correlation toward departing interval of patient suffering ischemic stroke. Malang Neurology Journal; 2020.6:63-68.

http://dx.doi.org/10.21776/ub.mnj .2020.006.02.3

\section{ABSTRACT}

Background: Ischemic stroke is an emergency state condition of brain which needs immediate rescue so the sufferer will not get any injury or risk of death. Interval of departing period still becomes problem. Level of severity perception and process of decision making of family are factors correlated to interval of departing time of the patient to Emergency Department.

Objective: The purpose of this research is to find out correlation of severity level perception and process of decision making of family to interval of departing time of patient suffering stroke to Emergency Department of Public Regional Hospital Blambangan Banyuwangi.

Methods: The method of this research is quantitative with cross sectional approach by involving 113 respondents. The technique of sampling is purposive sampling. The instruments are interview and observation sheet. The data analysis is done by spearman test to find out the correlation between variables namely level of severity and process of decision making of family's patient to interval of departing time.

Results: Findings show that $p$ value between perceptions of severity level to the interval is 0.000 and process of decision making of the family to the interval with $\mathrm{p}$ value $=0.000<\alpha 0.05$ meaning that variable of severity level and process of decision making are correlated to interval of departing time.

Conclusion: Nurses need to improve standard of stroke severity by determining half-body weakening symptom into severity of ischemic stroke then it is socialized to society and to let them know the importance of immediate transport to emergency department when ischemic stroke symptom is found.

Keywords: Level of severity perception, decision making of family, interval of departing time

\section{Introduction}

Stroke is blood flow disconnection to brain caused by broken or clogged vessels to brain. ${ }^{1}$ Based on pathology, stroke is grouped into two classifications: ischemic and homographic strokes. Research in the United State shows that 140.000 people dead each year because of stroke. ${ }^{2}$ And in every year, there are 795 thousand people suffering stroke. In developing country, stroke will increase in 2020 and becomes cause of death on the ages of \pm 45 year old. ${ }^{3,4}$

The high rate stroke number is also found in China with $19.9 \%$ of all death totals Go et $\mathrm{al}^{5}$, Research by Zhou et al ${ }^{6}$ from 1990 until 2013, stroke increased into 47.7\% in China, with percentage of incensement of ischemic stroke $143.3 \%$ higher than homographic stroke $17.9 \%$. According to Phillip et $\mathrm{al}^{7}$ and Evenson et $\mathrm{al}^{8}$ stroke is neurological damage cause and significantly affect mortality in Niger. Stroke complicated by coronary heart will increase in 2020 on ages of $\geq 45$ year old and becomes the main cause of losing healthy years ${ }^{3,9,10}$. In Korea, occurrence of stroke was 11.6 million in 2012. Ischemic stroke contributed $10.4 \%$ of death in Korea and in the world $19.6 \%$ from all 3.3 million deaths in the world. ${ }^{10}$
High death rate caused by stroke is assumed as caused by delay in giving immediate treatment or aid. It can be seen from interval of departing time of the patient when the patient arrives in ED. Some researches state that more than $50 \%$ acute ischemic stroke patients arrive in emergency room 3 hours after stroke attack..$^{3,11,12}$ In Japan, median interval of departing time of stroke patient to emergency room is 12.7 hours ${ }^{1}$. The extension of departing interval also occurs in India with $52.5 \%$ of patients arrive after 24 hours after stroke attack in emergency room. ${ }^{13,14}$ It is strengthened by Misbach \& $\mathrm{Ali}^{15}$ in 28 hospitals in Indonesia who stated that almost $78 \%$ of stroke patients arrive after 4.5 hours after the attack. The same thing also occurs in emergency room of Banyuwangi public regional hospital. Based on preliminary study, there are 52 medical records of patients suffering acute ischemic stroke. $79 \%$ of them arrive in emergency room after more than 6 hours.

In managing patients suffering stroke, there is a tem known as time is brain which refers to the already determined time for patients to have effective medication by using thrombolytic. Thrombolytic will provide positive impact when it is given to patients when they get the therapy 3 hours after the onset of the attack. ${ }^{16,17}$ It is proven by 
Meretoja's et all ${ }^{18}$ research stating that when the patient arrive quicker in emergency room and get thrombolytic therapy immediately then the patient's life expectation will increase 1.8 days with outcome $95 \%$. Based on metaanalysis toward patients visiting emergency room for less than 4 hours, it is gained improvement $80 \%$ of patient's prognosis after providing thrombolytic and only $10 \%$ fall into death.

Interval of departing time of patient is affected by various factors such as ages, races, environment, transportation, and financial. ${ }^{19,20}$ Other researches also state interval extension is correlated to knowledge of family, spot of the accident, stroke record, types of payment, and stroke severity. ${ }^{21,22}$ Besides those factors, according to Ellis ${ }^{23}$ some factors affecting the interval are centralized in decision making of family while providing treatment, communication, family support, and health empowerment. Slight of difference with results of Vidale's et $\mathrm{al}^{24}$ research stating that decision making is not correlated to interval of departing time of patient. It is different with Madsen et $\mathrm{al}^{25}$ who stated ages, races, situations of living, types of sex, and knowledge are not correlated to interval of departing time of patients to emergency room.

Based on the explanation, it has been explained some affective factors to arrival time of patients covering from knowledge, conscious, distance, previous stroke record, and types of used transportation. But, from several researches have not investigated how the correlation between severity level and decision making of family to interval of departing time of patient suffering stroke to emergency room. Because by using this knowledge should lead to better perception and appropriate decision making.

\section{Methods}

This research is a quantitative research. The design is observational analytic with cross sectional approach. The population of the research is all of responsibility takers/family of patients suffering ischemic stroke who come to ED of Blambangan Public Regional Hospital Banyuwangi with 113 respondents.

The data collection is done by using purposive sampling. There are five inclusive criteria 1) family is willing to be respondent, 2) patients who come to ICU suffering ischemic stroke, 3) patient is taken by private vehicle, 4) patient whom is taken directly by family and the family knows the process of stroke attack, 5) patients are using common payment of insurance. Meanwhile, the exculsive criteria are 1) referral ischemic stroke patient, 2) death ischemic stroke patient in the ED. The instruments are interview and observation sheets. The data collected by short interview with family of ischemic stroke patient for two months started from June 2018 - August 2018. This research has gained ethical improvement from Medicine Faculty of Universitas Brawijaya with number 151 / EC / KEPK - S2 / 06 / 2018. The collected data are then gathered, grouped, managed by analyzing, elaborated, discussed, and concluded. Techniques of analyzing data are univariate analysis to describe general or specific data of the variables and bivariate to assess severity level and process of decision making by using spearman test.

\section{Results}

There are result of univariate analysis and bivariate analysis in this article.

\section{Univariate Analysis}

Table 1. Characteristics of respondents

\begin{tabular}{|c|c|c|c|}
\hline Characteristics & Categories & Frequency & $\begin{array}{c}\text { Percentag } \\
\text { e }(\%)\end{array}$ \\
\hline \multirow{4}{*}{$\begin{array}{l}\text { Ages of } \\
\text { respondents }\end{array}$} & $25-45$ year old & 19 & $17 \%$ \\
\hline & $46-66$ year old & 91 & $80 \%$ \\
\hline & $>67$ year old & 3 & $3 \%$ \\
\hline & Total & 113 & $100 \%$ \\
\hline \multirow{3}{*}{$\begin{array}{l}\text { Sex types of the } \\
\text { patients }\end{array}$} & Male & 59 & $52 \%$ \\
\hline & Famle & 54 & $48 \%$ \\
\hline & Total & 113 & $100 \%$ \\
\hline \multirow{4}{*}{$\begin{array}{l}\text { Latest } \\
\text { Education }\end{array}$} & Not schooling & 2 & $2 \%$ \\
\hline & $\begin{array}{l}\text { Low } \\
\text { (Preliminary/Junior } \\
\text { High Schools) }\end{array}$ & 62 & $53 \%$ \\
\hline & $\begin{array}{l}\text { High } \\
\text { (SHS/University) }\end{array}$ & 51 & $45 \%$ \\
\hline & Total & 113 & $100 \%$ \\
\hline \multirow[t]{3}{*}{ Occupations } & Employed & 79 & $70 \%$ \\
\hline & Unemployed & 34 & $30 \%$ \\
\hline & Total & 113 & $100 \%$ \\
\hline
\end{tabular}

Based on the table 1, it can be seen that from 113 respondents, the most dominant frequency about age is elder category (46-66) year old with total 91 respondents. The most dominant sex type is male by 59 respondents. The dominant education is low education by 62 respondents. Most of the respondents are employed or work.

Table 2. Respondent variable

\begin{tabular}{llcc}
\hline \multicolumn{1}{c}{ Variable } & \multicolumn{1}{c}{ Categories } & Frequency & Percentage \\
\hline Conscious & 15 (Compos Mentis) & 33 & $29 \%$ \\
\cline { 2 - 4 } level & $12-14$ (Apatis) & 65 & $58 \%$ \\
\cline { 2 - 4 } (CGS) & $10-11$ (Delirium) & 15 & $13 \%$ \\
\cline { 2 - 4 } & Total & $\mathbf{1 1 3}$ & $\mathbf{1 0 0 \%}$ \\
\hline \multirow{2}{*}{ Perception } & Severe & 64 & $43 \%$ \\
\cline { 2 - 4 } & Not severe & $\mathbf{1 1 3}$ & $\mathbf{1 0 0 \%}$ \\
\cline { 2 - 4 } & Total & 23 & $20 \%$ \\
\hline \multirow{2}{*}{$\begin{array}{l}\text { Decision } \\
\text { Making }\end{array}$} & 2 stages & 78 & $63 \%$ \\
\cline { 2 - 4 } Steps & 3 stages & 12 & $11 \%$ \\
\cline { 2 - 4 } & 4 stages & $\mathbf{1 1 3}$ & $\mathbf{1 0 0 \%}$ \\
\cline { 2 - 4 } & Total & &
\end{tabular}

Based on the table 2, it can be seen that from 113 patients suffering stroke most of them have apathetic conscious with scores of GCS between 12 and 13 for 65 patients. Perceptions of the respondents or family with complaint or emerging symptoms from their families suffering stroke are mostly argued the patients are not severe, seen on 64 respondents. Based on table 5.3, it can be seen from 113 respondents most of them have passed through three stages in making decision.

Based on the table 3, average of waiting time of family agreement is 28 minutes. Average time of heading/going to alternative medication is 41 minutes. Meanwhile, the length of time of going to nurses/doctors/clinics is 29 minutes and length of time needed to go to hospital is about 39 minutes.

Based on the table 4, it is gained that the interval of departing time of patients to ED is about 189 minutes with minimum time 80 minutes and maximum time 275 minutes. 
Table 3. Characteristic distribution

\begin{tabular}{|c|c|c|c|c|c|c|}
\hline $\begin{array}{l}\text { Stages of Decision Making of } \\
\text { the Families }\end{array}$ & $\mathbf{N}$ & Mean & $\begin{array}{c}\text { Standard } \\
\text { Deviation(SD) }\end{array}$ & $\begin{array}{l}\text { Median (minimum- } \\
\text { maximum) }\end{array}$ & \multicolumn{2}{|c|}{$95 \% \mathrm{CI}$} \\
\hline Waiting agreement & 113 & 28.27 & 14.012 & $30(10-65)$ & 25.7 & 30.9 \\
\hline Alternative Medication & 53 & 41.42 & 13.530 & $40(20-65)$ & 37.7 & 45.1 \\
\hline $\begin{array}{l}\text { Going to see } \\
\text { nurses/doctors/clinics }\end{array}$ & 53 & 29.06 & 10.426 & $30(10-60)$ & 26.2 & 31.9 \\
\hline Heading to hospital & 113 & 38.07 & 13.555 & $35(10-75)$ & 36.2 & 41.2 \\
\hline
\end{tabular}

Table 4. Distribution of the respondents

\begin{tabular}{ccccccc}
\hline Variable & N & Mean & $\begin{array}{c}\text { Standard } \\
\text { Deviation(SD) }\end{array}$ & $\begin{array}{c}\text { Median (Minimum } \\
\text { - Maximum) }\end{array}$ & 95\% CI \\
\hline Interval of Departing Time & 113 & 189.24 & 48.869 & $195(80-275)$ & 180.1 & 198.3 \\
\hline
\end{tabular}

\section{Bivariate Analysis}

Table 5. Bivariate analysis

\begin{tabular}{cc}
\hline Variable & Interval of Departing Time \\
\hline Perception of Severity & $\mathrm{r}=-0.720$ \\
Level & $\mathrm{p}=0.000$ \\
& $\mathrm{n}=113$ \\
\hline Variable & Interval of Departing Time \\
\hline Decision Making of & $\mathrm{r}=0.509$ \\
Family & $\mathrm{p}=0.000$ \\
& $\mathrm{n}=113$ \\
\hline
\end{tabular}

Based on the table 5, spearman correlative test result gains score $\mathrm{p}=0.000$, showing that there is correlation between severity level perception and interval of departing time. Pearson score correlation is about -0.720 , showing strong negative correlation. It means when the perception is getting worst, it takes longer time of departing interval of the patients to ED. Based on the table, $\mathrm{p}$ score is 0.000 , showing that there is correlation between decisions making to interval of departing time. Pearson correlative score is 0.509 , showing intermediate positive correlation. It means many stages in decision making, it takes longer interval of departing time of the patients.

\section{Discussion}

\section{Correlation Perception of Severity Level to Interval of Departing Time}

Perception is a reception upon something. ${ }^{26}$ Perception is a process started by sensing accepted by senses in the form of stimulus then it is forwarded to central neurons - the brain, so a psychological process occurs then the individual is aware of what is being seen, listened, and so forth in which are called as process of perception. ${ }^{27,28,29}$ Perception is defined more applicative as ability to differ, to group, to focus, and to be interpreted. ${ }^{29}$ Perception of severity level of a disease is an individual's perception whether a disease is severe or not. This perception functions as basic understanding and fostering pattern of actions. ${ }^{30}$ Thus, what is meant by perception of severity level of patients is an individual's ability to initially observe stroke symptoms and to differ as well as to interpret the condition suffered by sufferer whether it is severe or not.

Perception of severity level is correlated to interval of departing time of the patient. This perception is different from one to another in perceiving emerging symptom of patients suffering ischemic stroke. The most frequently appearing symptoms are changes of conscious level, asymmetric face, weakening of half part of body, unclear speaking, and feeling numb when is touched on weakening body parts. However, not all of the symptoms appear. There may be only two or may be more symptoms appearing. It is then called as perception of severity level of ischemic stroke patients. When the perceptions of the family is getting worst, then it takes longer time for them to take the patients to Emergency Department. Research in America done by Malek et $\mathrm{al}^{31}$ also found perception about stroke symptoms as emergency state condition will shorten interval of departing time to emergency room.

The sufferers are interpreted severe by families when their conscious levels are decreasing; their face are asymmetric; they have weakening parts of body; and they unclearly speak. There are 20 respondents who consider conscious level as indicator of severity level. The reason of the family makes it as indicator because when an individual loses his conscious, it leads to comma or even death. It is in line with assessment done by nurses during reviewing patient's onset at emergency unit. When it is seen from GCS score (Glasglow Comma Scale) of the sufferer, the score is in $11-13$.

There are 27 respondents interpret severe condition by two or three symptoms such as asymmetric face, weakening left body part, and unclearly speaking. The families make the weakening symptom of left body part as indicator of severity because several families are afraid something worse happened to their family suffering the disease. The respondent also state that there is previous experience of his other relative and neighbor whom ever got similar symptoms started by weakening body part. Then, when it is underestimated, it leads to death. The sufferers still have good conscious or even completely conscious. When it is assessed by GCS, then the score is in 15. Although when it is assessed by using conscious level measurement, it is not categorized as severe based on GCS score. This is a good response from the families whom want to take the patients so they are still completely conscious when the sufferers are sent off to the hospital for immediate treatment. The interval of departing time also get shortened if the families have this perception.

However, beside this condition, there are also some families interpreting the conditions as not severe although GCS scores are in 10 until 11 or 11 until 13. This perception is not in line with assessment of conscious level. There is underestimating element upon the symptoms of the patients. This perception is correlated to understanding that the sufferers are only exhausted so they are difficult to be woken up. There are also 
some of families stating that the disease is caused by other people who hate the person or because the sufferers are being complimented too much so it makes them sick. Besides that, the losing conscious condition is considered as impacts of fatigue after working. So, even the sufferers' conscious decrease, their families' perceptions do not show that ischemic stroke sufferers are in severe level. It is also supported by Hopman ${ }^{21}$ stating that severity of diseases influence mindset and habits to related diseases. It is important because patients will form understanding and reasoning internally about a certain condition based on that perception.

Before the perception appears, an individual living with the sufferer should be the first to detect the symptom based on observation or complaints of the sufferer. The perception will appear frequently with proper knowledge owned by an individual who catches the initial condition of stroke sufferer. When their families interpret it as severe during finding out the symptom, it will speed up interval of departing time of the patients to ED because the families directly send off the sufferer. Most of family will interpret an emergency condition if the sufferers' conscious level decrease, indicated by lower response when they are called. Perception about stroke symptom must be equated started from individual until society levels so people will directly send of their families suffering ischemic stroke to ICUs which are capable of rescuing them.

Conscious level is important to be consideration in implementing level of severity. In medical service, conscious is assessed by GCS (Glasgow Coma Scale) as indicators of ischemic stroke patients to be stated severe or not. When the score of GCS is higher, it shows an individual's conscious is good. Then, when the score is lower, it shows an individual's conscious level of ischemic stroke patient is bad.

Based on the research, it is gained that greater GCS score of the patients, their time to go to the ED take longer time. It is caused due to normal conscious existence although some body parts get weaker so their families' perceptions conclude the conditions do not indicate stroke or the conditions indicate stroke but they are not severe. Therefore, the families do not take the patients immediately to the ED. When the patients arrive at the ED, then their conscious are assessed by nurses and compared to other families' perceptions, there is something unmatched. More than $50 \%$ of ischemic stroke sufferer sent off to the ED have their conscious decrease.

\section{Correlation of Decision Making of Family to Interval of Departing Time}

Decision making of family is a choice taken by families in deciding action to do. In this decision making of the families, there are several stages to choose when they find the symptoms on one of their families - they are waiting for agreement, sending to alternative medication, seeing doctors/nurses/clinics, and sending to hospital.

Waiting for agreement is important thing in a family because it is initiated by discussion of family party via various knowledge and experiences. Waiting for agreement becomes an important thing for a family. It determines decision to take after having discussion in family. Interval of agreed time is also influenced by the most influencive person in the family who later accelerates or delays the sufferer to be sent to the hospital.
Taking or sending to alternative medication is taking to traditional medication to experts living near the sufferer's house. This action is still believed to be potent in curing the sufferer. Generally, people still believe this type of medication because they believe the disease of sufferer is due to voodo. Sending to alternative medication is family choice to get treatment when their families sick. This option is still preferred for most of Banyuwangi citizens because they still believe that such disease is caused by voodo. Thus, they decide to take the sufferers to alternative medication. It is also suggested by patient's neighbors whom still suggest to go to alternative medication because they believe such disease can be cured by a gifted person.

Taking to clinics/doctors/nurses is also option for families to handle when there is one of their families sick. Besides that, people also have believe that when they see doctors then they get injection, their pain will be relieved. The families' action to take the sufferer is considered to be an appropriate action but after seeing doctor and they take the sufferer home with many excuses even the doctors have suggested to go to hospital.

According to Miller ${ }^{32}$, management of ischemic stroke started by onset face of the symptom until decision to get assistance of meidcal workers or EMS, determining to contact medical workers immediately and from medical workers of hospital who have abilities to provide definitive therapy for patients suffering acute ischemic stroke. Then, the longest phase is decision making from onset of the symptom until to determine medical workers whom become reference to get medication. The average of time needed is about $42-45$ minutes. A study by Mellor et $\mathrm{al}^{33}$ with qualitative method in Western Midland, England shows three potencies of delay are identified started from the emergence of the symptom until contacting medical workers or health service provider. Primary delay is caused by lack of symptom recognition. Secondary delay is caused initial contact with non-emergent service. Tertiary delay is caused by health service provider who does not interpret the condition as stroke symptom. There are some different ways to take between the overseas countries to Indonesia because of inherited belief of Indonesian people which considers horrible disease is caused by non-physical disease.

Beside stages in decision making, initial emergence of stroke symptom until it is found by one of family members also contributes the length of departing time interval. Many causes of the delay are about early detection of ischemic stroke symptom, person in charge of working condition so they must go home first then they know the condition of sufferers. Stroke symptoms also appear when all family members rest. The length of detecting time also influences interval of departing time.

Directly going to ICU is an appropriate choice to do by several families of ischemic stroke patients after waiting for agreement. By taking the sufferers directly to $\mathrm{ED}$, interval of departing time becomes shorter so windows period of the patients' \pm 3 hours can be achieved and medication by using rTpa can thrombolytic impact. ${ }^{16,34,35}$

Decision making is also correlated to who decide it. In core family, decision making is usually done by husband, wife, or child. In this research, there is no correlation between decisions making to interval of departing time. But in the 
reality, there is difference of time when a husband, wife, or child take the patients. Child as decision maker averagely contribute longer time compared to husband or wife. Based on Kuczynski et $\mathrm{al}^{36}$ in Columbia about arrival time at ED shows that a man living alone or a divorced man is significantly lesser to arrive $\leq 3$ hours compared to a man living with his couple or a married man. Meanwhile, when it is on woman living alone or a divorced woman, the woman has equal arrival time opportunity at $\mathrm{ED} \leq 3$ hours compared to woman living with her couple. So, in the research when a wife as a decision maker, she will directly take her husband to ED. ${ }^{37}$

In Fransisco, a research by Bank's \& Dracup ${ }^{38}$ gains median of female patients' delays are longer than male patients with different in time 4.4 hours vs 3.5 hours. It is similar to Bertakis $^{39}$ showing that woman tend to choose to make decision directly to go to clinic or advance health service - a hospital compared to male patients. So, when there is a family member sick and the person in charge is a woman, then it shortens interval of departing time of patients to ED. Besides that, unemployed female can directly detect and find family members whom are sick so they directly take them to ED. ${ }^{37}$

It is different to Alsharani et $\mathrm{al}^{40}$, by using mix method technique in Saudi Arabica, they found females as predictors to lengthen interval of departing time compared to median time between man and woman (5 hours and 12.9 hours). From qualitative analysis, it is gained five themes because woman needs permission from her male relatives to accompany sufferers to health service because woman cannot go somewhere except being accompanied by her male siblings. Woman prioritizes her responsibility to seek assistance. They have less understanding of disease symptom. They have perceptions that woman should not attract many attention.

\section{Conclusion}

Based on the findings, it can be concluded that there is negative and significant perception between severity level and interval of departing time of ischemic stroke patients. There is significant and positive correlation between decision making of family and interval of departing time to the ED. The hospital needs to create codes for stroke. The nurses at emergency room must promote socialization for patients' families and societies about the importance of minimum times for patients to arrive at emergency room earlier when the patients get ischemic stroke attack. Besides that, nurses at emergency room must be responsive to accept onsets of patients suffering ischemicstroke.

\section{Acknowledgement}

I express my gratitude to my family, then Banyuwangi Institute of Health Sciences who have supported this research and Blambangan District Hospital which has given research permission.

\section{References}

1. Yanagida T, Fujimoto S, Inoue T, Suzuki S. Causes of prehospital delay in stroke patients in an urban aging society. J Clin Gerontol Geriatr; 2014. 5(3):77-81.

DOI: 10.1016/j.jcgg.2014.02.001

2. Benjamin EJ, Blaha MJ, Chiuve SE, Cushman M, Das $\mathrm{SR}$, Deo R, et al. Heart disease and stroke statistics'2017 update: A report from the American Heart Association. Circulation. 2017. 135:146-603. DOI: 10.1161/CIR.0000000000000485

3. Stein Joel, Richard L Harvey, Carolee J Winstein, George F Wittenberg. Recovery and rehabilitation in stroke. Stroke; 2004.2691-2694.

DOI: 10.1161/01.STR.0000143323.84008.f4

4. Saposnik G, Kapral MK, Liu Y, Hall R, O’Donnell M, Raptis S, et al. IScore: A risk score to predict death early after hospitalization for an acute ischemic stroke. Circulation; 2011. 123(7):739-49.

DOI: $10.1161 /$ CIRCULATIONAHA.110.983353

5. Go AS, Mozaffarian D, Roger VL, Benjamin EJ, Berry JD, Borden WB, et al. Heart disease and stroke statistics-2013 Update. Circulation [Internet]; 2013. Jan;127(1). Available from: https://www.ahajournals.org/doi/10.1161/CIR.0b013e31 828124advvvv

6. Zhou Y, Yang T, Gong Y, Li W, Chen Y, Li J, et al. Pre-hospital delay after acute ischemic stroke in central urban China: Prevalence and risk factors. Mol Neurobiol; 2017;54(4):3007-16. DOI: 10.1007/s12035016-9750-4

7. Philip-Ephraim EE, Charidimou A, Otu AA, Eyong EK, Williams UE, Ephraim RP. Factors associated with prehospital delay among stroke patients in a developing African country. Int J Stroke; 2015. 10(4):E39-E39. DOI: $10.1111 /$ ijs. 12469

8. Evenson KR, Foraker RE, Morris DL, Rosamond WD. A comprehensive review of prehospital and in-hospital delay times in acute stroke care. Int J Stroke; 2009. 4(3):187-99. DOI : 10.1111/j.1747-4949.2009.00276.x

9. Moser DK, Kimble LP, Alberts MJ, Alonzo A, Croft JB, Dracup K, et al. Reducing delay in seeking treatment by patients with acute coronary syndrome and stroke. Circulation; 2006. 114(2):168-82.

DOI: $10.1161 /$ CIRCULATIONAHA.106.176040

10. Mozaffarian D, Benjamin EJ, Go AS, Arnett DK, Blaha MJ, Cushman M, et al. Executive summary: Heart disease and stroke statistics-2016 update: A Report from the American Heart Association. Circulation; 2016. 133(4):447-54.

DOI: 10.1161/01.cir.0000441139.02102.80.Heart

11. Siddiqui M, Siddiqui SR, Zafar A, Khan FS. Factors delaying hospital arrival of patients with acute stroke. J Pak Med Assoc; 2008. 58(4):178-82. DOI: 18655425

12. Jin $\mathrm{H}$, Zhu S, Wei JW, Wang J, Liu M, Wu Y, et al. Factors associated with prehospital delays in the presentation of acute stroke in urban China. Stroke; 2012. 43(2):362-70. DOI: 10.1161/STROKEAHA.111. 623512

13. World Health Orgnization. Global status report on noncommunicable diseases; 2014. Avalaible from: https://apps.who.int/iris/bitstream/handle/10665/148114/ 9789241564854_eng.pdf 
14. Ashraf VV, Manesh M, R. Praveenkumar, K. Saifudheen, A. S. Girija. Factors delaying hospital arrival of patients with acute stroke. Annals of Indian Academy of Neurology; 2015. Apr-Jun;18(2):162-6. Pubmed Central PMCID: PMC4445190.

DOI: 10.3389/fneur.2017.0061

15. Misbach, J. Stroke in Indonesia: A fisrt large prospective hospital based study of acute stroke in 28 hospitals in Indonesia. Journal of Clinical Neuroscience; 2001. 8(3), 245-249. DOI: 10.1054/jocn.1999.0667

16. Hassankhani H, Soheili A, Vahdati SS, Mozaffari FA, Fraser JF. Treatment delays for patients with acute ischemic stroke in an iranian emergency department : A retrospective chart review. Ann Emerg Med [Internet]; 2018. 1-12. DOI: 10.1016/ j.annemergmed.2018.08.435

17. Wilson SE, Ashcraft S. Ischemic Stroke: Management by the nurse practitioner. J Nurse Pract [Internet]; 2019. 15(1):47-53.e2. DOI: 10.1016 /j.nurpra.2018.07.019

18. Meretoja A, Strbian D, Mustanoja S, Tatlisumak T, Lindsberg PT, Kaste M. Reducing in-hospital delay to 20 minutes in stroke thrombolysis. Neurology; 2012. 79(4):306-313. DOI: 10.1212/WNL.0b013e3182 $5 \mathrm{~d} 6011$

19. Borhani Haghighi A, Karimi AA, Amiri A, Ghaffarpasand F. Knowledge and attitude towards stroke risk factors, warning symptoms and treatment in an Iranian population. Med Princ Pract; 2010. 19(6):468-72

20. Saudin, D. Agoes, A. Setyorini I. Analisis faktor yang mempengaruhi keterlambatan dalam mengatasi pasien stroke saat merujuk ke rsud jombang. Jurnal Kesehatan Hesti Wira Sakti; 2016. 4(2):1-12. Available from: http://garuda.ristekdikti.go.id/documents/detail/583606

21. Hopman P, Rijken M. Illness perceptions of cancer patients : Relationships with illness characteristics and coping; 2015. Jun;18:11-8. DOI: 10.1002/pon.3591

22. Rachmawati D, Andarini S, Ningsih DK. Pengetahuan keluarga berperan terhadap keterlambatan kedatangan pasien stroke iskemik akut di Instalasi Gawat Darurat. Jurnal Kedokteran Brawijaya; 2017. 29(4):369-76. Available from: http://jkb.ub.ac.id/index. php/jkb/article/view/1783/585

23. Ellis C. In-hospital delays for stroke care : Losing sight of patient- centered care. European Journal for Person Centered Healthcare; 2013. 1(2):381-384. Avalaible from:

https://pdfs.semanticscholar.org/5730/6ac33c5da3d06ea 95ee23f6008e6dc04c238.pdf

24. Vidale S, Beghi E, Gerardi F, De Piazza C, Proserpio S, Arnaboldi M, et al. Time to hospital admission and start of treatment in patients with ischemic stroke in northern italy and predictors of delay. Eur Neurol; 2013. 70(56):349-55. DOI: 10.1159/000353300

25. Madsen TE, Sucharew H, Katz B, Alwell KA, Moomaw CJ, Kissela BM, et al. gender and time to arrival among ischemic stroke patients in the greater cincinnati/northern kentucky stroke study. J Stroke Cerebrovasc Dis [Internet]; 2016. 25(3):504-10.

DOI: $10.1016 /$ j.jstrokecerebrovasdis.2015.10.026

26. Walgito, Bimo. General Psychology. Yogyakarta: Andi Offset; 2003.75-77. ISBN: 979-731-088-4
27. Fitriyah L \& Jauhar M. Introduction of general psychology. Jakarta: Prestasi Pustakaraya Publisher; 2014.

28. Setiawan, E. Kamus Besar Bahasa Indonesia (KBBI); 2014. Avalaible form: http://kbbi.web.id/sistem

29. Sarwono, SW. Introduction general psychology. Jakarta: PT. Rajagrafindo Persada; 2010. Page: 93-103. ISBN: 978-979-769-257-5

30. Suls J \& Wallston KA. (Eds.). Blackwell series in health psychology and behavioral medicine. Social psychological foundations of health and illness. Malden: Blackwell Publishing; 2003.

DOI: $10.1002 / 9780470753552$

31. Malek AM, Adams RJ, Debenham E, Boan AD, Kazley AS, Hyacinth HI, et al. Patient awareness and perception of stroke symptoms and the use of 911. J Stroke Cerebrovasc Dis; 2014. Sep;23(9):2362-71. DOI: 10.1016/j.jstrokecerebrovasdis.2014.05.011

32. Miller DL. Acute Stroke: It's all about process and team improving patient outcomes in the emergency department. J Radiol Nurs [Internet]; 2016. 35(3):198204. DOI: http://dx.doi.org/10.1016/j.jradnu. 2016.06.007

33. Mellor RM, Bailey S, Sheppard J, Carr P, Quinn T, Boyal A, et al. Decisions and delays within stroke patients' route to the hospital: A qualitative study. Ann Emerg Med; 2015. 65(3):279-287.e3

DOI: 10.1016/j.annemergmed.2014.10.018

34. O’Brien EC, Xian Y, Xu H, Wu J, Saver JL, Smith EE, et al. Hospital variation in home-time after acute ischemic stroke: Insights from the PROSPER study (Patient-Centered Research into Outcomes Stroke Patients Prefer and Effectiveness Research). Stroke; 2016. 47(10):2627-33. DOI: 10.1161/STROKEAHA. 116.013563

35. Husna M, Kusworini, Wulansari DA. Research article correlation between leukocyte count when admitted in Emergency Room (ER). MNJ; 2015. 2(1):46-51. DOI: http://dx.doi.org/10.21776/ub.mnj.2015.001.02.1

36. Kuczynski H, Parikh NS, Goldmann E, Madsen TE, Roberts ET, Boden-Albala B. gender, social networks, and stroke preparedness in the stroke warning information and faster treatment study. J Stroke Cerebrovasc Dis [Internet]; 2017. 26(12):2734-41. DOI: 10.1016/j.jstroke cerebrovasdis.2017.06 .046

37. Saikia N, Moradhvaj, Bora JK. Gender difference in health-care expenditure: Evidence from India human development survey. PLoS One; 2016. 11(7):1-15. DOI: 10.1371/journal.pone.0158332

38. Banks AD, Dracup K. Are there gender differences in the reasons why African americans delay initial symptom experience for symptoms of an acute myocardial infarction?; 2007. June. PMID:17682349

39. Bertakis KD, Azari R. Patient-Centered Care: The Influence of patient and resident physician gender and gender concordance in primary care. J Women's Heal; 2011. 21(3):326-33. DOI: 10.1089/jwh.2011.2903

40. Alshahrani H, McConkey R, Wilson J, Youssef M, Fitzsimons D. Female gender doubles pre-hospital delay times for patients experiencing ST segment elevation myocardial infarction in Saudi Arabia. Eur J Cardiovasc Nurs; 2013. 13(5):399-407.

DOI: $10.1177 / 1474515113507159$ 